\title{
Varga László \\ Brassai Sámuel és kortársai a magyar mondat hangsúlyozásáról
}

1. Brassai Sámuel a magyar mondat inchoatívumra és mondatzömre osztja (Brassai 1863-65. 297-306). Az É. Kiss Katalin-féle transzformációs generatív modellben ezek a topic és comment fogalmainak felelnek meg (É. Kiss 1978, 1981a, 1987). Az inchoatívum (topic) nem kötelező elem, a mondatzöm (comment) kötelező.

Brassai egyetlen elsőrendü hangsúlyt enged meg a magyar mondatban: ez vagy az igére, vagy az ige előtti bővítményre, tehát a mondatzöm első tagjára, az ún. ,jelzőre” esik (Brassai 1888. 24; vö. 1889. 343). Ez azonos az É. Kiss-féle fókuszpozícióval vagy F-pozícióval a comment élén. Brassai szerint az ige mögötti bővítménnyel legfeljebb másodrendủ hangsúlyt kapnak (1888. 27; vö. 1889. 398), az inchoatívum pedig még másodrendü hangsúlyt sem kaphat (1889. 399). Mindezt az (1) ábra foglalja össze:

(1)

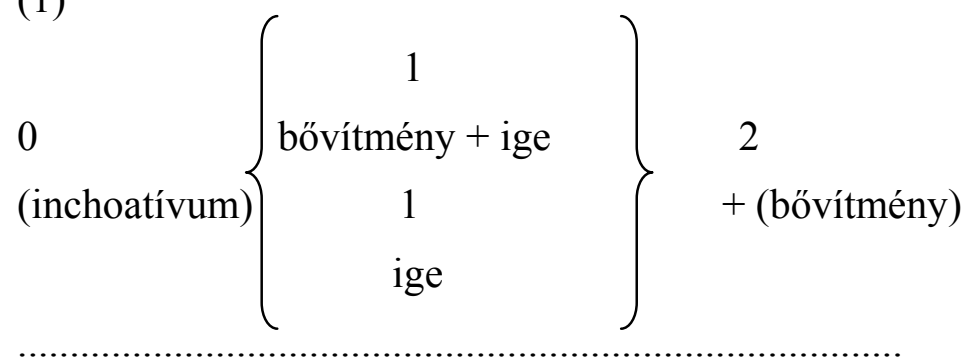

zöm

2. A magyar mondat hangsúlyozásának ezzel a jellemzésével Brassai kortársai kezdettől fogva vitatkoztak. Azt senki sem tagadta, hogy a leírt hangsúlyozási lehetőség létezik. A vitatkozók azt kifogásolták, hogy a modell más hangsúlyozási lehetőségekre nincsen tekintettel, holott a Brassai által leírt hangsúlyozás nem az egyetlen, de még csak nem is az alapvető lehetőség.

Így éles vita kerekedett a magyar mondathangsúlyozás dolgában Brassai és Joannovics György között. A vita egyik oka a szórend és hangsúlyozás kölcsönhatásával volt kapcsolatos. A vitának ez a része a mi vizsgálódásunk szempontjából kevésbé érdekes, és úgy foglalható össze, hogy Brassai és Joannovics más-más tényezőben vélte megtalálni a magyar szórend kulcsát. Brassai - a Fogarasi-féle hagyományhoz híven - úgy látta, hogy szórendünknek az akcentus (értsd: a hangsúly) a kulcsa (Brassai 1889. 343; vö. 1888). Joannovics szerint viszont a szórendet elsősorban a szavak nyelvtani értéke határozza meg (Joannovics 1889. 61; 1903. 17-8). A vitának számunkra érdekesebb vonulata a magyar mondat hangsúlyozásának Brassai által felállított modelljével kapcsolatos.

Joannovics György úgy látta, hogy Brassai „olyan hangsúlyozást teremt, a mely a magyar beszédet megfosztja accentusainak nagyobb részétől” (Joannovics 1889. 103). Szintén Joannovics mondja: „'Nemtudott eszme' és 'másodrendű hangsúly’: Ez a kettő nem illik együvé." (i.m. 110). Joannivics azt állítja, hogy a valóságban az ige utóbbi bővítmények, ha nem-tudott (azaz új) információt hordoznak, bizony éppúgy elsőrendủ hangsúlyt kapnak, mint a zöm élén álló elem: Ha nem fizetsz 'te, fizet 'az öcséd (1903. 362). (A különböző forrásokból származó példák hangsúlyjelölését egységesítem. A ' $x$ jelet az elsőrendü 
hangsúly, a ,x jelet a másodrendủ hangsúly, a “ $x$ jelet pedig a különlegesen kiemelt elsőrendü hangsúly jelölésére használom. V.L.)

Joannovics arra is rámutat, hogy a mondatzöm elött, az inchoatívumban is állhat elsőrendü hangsúlyú bővítmény, méghozzá több is, ha ezek pozitív természetüek, pl. Hát 'ilyenkor is 'mindig a 'föcélt kell szem elött tartani (i.m. 104).

Joannovicshoz hasonlóan Simonyi Zsigmond (1880) is azon a véleményen van, hogy az inchoatívum hangsúlyos is lehet, ha pozitív jellemü kifejezés(pl. nagyon, annyira, sok, mind, vagy is-sel kapcsolt fogalom) áll benne; továbbá, hogy a mondatzömben is lehetséges több egyforma hangsúly. Tanulságos e tekintetben Simonyi összefoglalása az ige + igekötő szerkezet hangsúlyozási lehetőségeiről és ezek okairól. Ezek összefoglalására az ún. „fordul elő” kérdés adott alkalmat. Simonyi egyik korábbi mondatában (Az é mélyhangú mondatokban is fordul eló) a fordul elö szerkezetet többen kifogásolták. Válaszában Simonyi (1884) megállapítja, hogy az ige + igekötő szerkezetnek négyféle hangsúlyozása lehetséges, és a négy lehetőség között olyan is akad, amelyben az elülső ige hangsúlytalan és a rá következő igekötő hangsúlyos, meg olyan is, amelyben mind az ige, mind a rá következő igekötő egyformán hangsúlyos. Egy későbbi cikkében (1902) a higgadt, egyenletes hangsúlyozású mondatokat nyomatéktalan, az egy fogalmat különösen kitüntető mondatokat pedig nyomatékos mondatoknak nevezi (i.m. 58. kk.). Brassai véleményével szemben megállapítja, hogy a nyomatéktalan mondat „tüzetes részében” (mondatzömében) több, egyenlő erejü hangsúly sorakozhat (pl. Én 'vittem neki 'bort; i.m. 123), sőt arra is rámutat, hogy az ige „előkészítő rész” (inchoatívum) is lehet (pl. Forditotta meg 'Szász Károly; i.m. 128). Részletesen elemzi a nyomatékos mondatok négy osztályát, tehát az összefoglaló, kirekesztő, felszólító és kérdő mondatoknak a hangsúlyviszonyait és azok funkcióit (i.m. 59. kk.).

De Joannovicshoz és Simonyihoz hasonlóan vélekedett Balassa József és Kicska Emil is. Balassa szerint az alany és az állítmány ejthető egyforma erővel is (1887-90. 408), más szóval az inchoatívum éppolyan hangsúlyos lehet, mint a mondatzöm. Balassa is elmondja, hogy az állítmány utáni bővítmények ugyanolyan nyomatékot kaphatnak, mint az állítmány (i.m. 418). Balassa szerint Brassai téved, amikor egyedül az állítmány szólamát tartja hangsúlyos résznek, mert „mind az inchoatívumban, mind az egészítményben lehetnek fontos kiemelt részek” (i.m. 431). (Az „egészítmény” Balassánál az ige utáni rész, V.L.)

Kicska Emil (1891) szerint Brassai azért nem ismeri el, hogy a mondatban több elsőrendü hangsúly sorakozhat, mert a mondatokat kérdésekre adott feleleteknek fogja fel! Vagyis Brassai nem érzi a két egyforma hangsúlyt például ebben: a 'legutolsó parasztnak is ‘̈röm volt a dolga, hiszen ha a mondat arra felel, hogy kinek volt öröm a dolga, akkor csak az elülső hangsúly indokolt, ha viszont arra válaszol, hogy milyen volt a dolga a legutolsó parasztnak is, akkor csak a hátulsó hangsúly tartható meg (i.m. 343). Kicska (i.m. 337-45) az elsőrendü hangsúlynak két fokozatát különbözteti meg: a „mondó” hangsúlyt (pl. A csikó 'zabot eszik; i.m. 339), és az „ellentmondó” hangsúlyt (pl. A 'csikó eszik zabot; i.h.; vö. még Kicska 1890. 7. kk.). Bár a mondó és az ellentmondó hangsúly fonetikailag egyforma erejü is lehet, az ellentmondó hangsúly általában erösebb (1891.339).

Kicska szerint gyakori jelenség, hogy az ige és az utána álló bővítmény egyforma erejü mondó hangsúlyt kap; így pl. A 'vág 'fát szerkezet a cselekvés folyamatosságát mutatja (i.m. 386); sőt az sem ritka, hogy az ige utáni bővítmény erősebb hangsúlyt kap, mint maga az ige, pl. 'vág 'fát (,de nem 'húst) (i.m. 387); a vásáron vettem két 'lovat, négy 'ökröt, egy 'csikót, húsz juhot (i.m. 394). A többiekhez hasonlóan, Kicska az inchoatívum hangsúlyozását illetően is szembehelyezkedik Brassaival, méghozzá nemcsak olyan esetekben, ahol pozitív kifejezésről van szó. Elismeri, hogy az inchoatívum általában valóban gyengébb hangsúlyú, mint a zöm élén álló elem, de azért a kettő hangsúlya egyforma is lehet. Tehát ahelyett, hogy 
az ,új országgyülésen 'kemény tusák lesznek, ezt is mondhatjuk: Az 'új országgyülésen 'kemény tusák lesznek (1895. 341). Ami a szórend kérdését illeti, abban Kicska sem Brassainak, sem Joannovicsnak nem ad igazat (1891. 294); szerinte a magyar szórendnek nem a hangsúly, de nem is a szavak nyelvtani értéke a kulcs, mert azt csak a kirekesztés és összefoglalás értelmi műveletei magyarázzák meg kielégítően. Ezért mind a 'Jól megtanulta, mind a "Jól tanulta meg mondat helyes, csak az első esetben összefoglalás, a másodikban kirekesztés az értelem müvelete (i.m. 297-298).

3. Összefoglalva, míg Brassai a magyar mondatban csak egyetlen elsőrendű hangsúlyt enged meg, éspedig a zöm élén álló elemen, addig Brassai kritikusai emellett olyan további hangsúlyozási lehetőségekre hívták fel a figyelmet, amelyekben a mondat több elsőrendü hangsúlyt tartalmaz, illetve amelyekben az egyetlen elsőrendü hangsúly a zöm belsejében az ige utáni elemre esik. Megjegyzem, hogy ezek a vélemények egybecsengenek a 20. századi magyar nyelvészetben található álláspontok túlnyomó többségével is. (Lásd erről Varga 1986: 186).

Az ismertetett véleményekben talált kritikai észrevételek a (2) és (3) pontban gyüjthetők össze:

(2) Nem áll, hogy a mondatzömben az ige után sorakozó bővítmények csak másodrendü hangsúlyt kaphatnak,

a. mert ezek gyakran ugyanolyan hangsúlyt kapnak, mint a mondatzöm elején álló elem, vagyis éppúgy elsőrendü hangsúlyúak lehetnek, mint az;

b. mert ezeknek a bővítményeknek a hangsúlya alkalmasint még kiemelkedőbb lehet, mint a mondatzömben élén álló elem hangsúlya;

(3) Nem áll, hogy az inchoatívumban még másodrendü hangsúlyok sem lehetnek (vagyis hogy az inchoatívum csak hangsúlytalan lehet).

a. mert az itt található bővítmények, ha pozitív jellemü kifejezések, éppúgy elsőrendü hangsúlyúak, mint a zöm élén álló elem vagy a zöm belsejében levő új bővítmények;

b. mert az itt található bővítmények akkor is elsőrendü hangsúlyúak lehetnek, ha nem pozitív jellemü kifejezések, de új információt hordoznak.

Lássuk most a felsorolt kifogásokat sorjában.

4. A (2a) szerint a mondatzömben (tehát az É. Kiss-féle értelemben vett commentben) az ige utáni bővítmények is éppúgy hangsúlyozhatók, mint a mondatzöm elején álló elem. Ez kétségtelen tény. Hogyan magyarázható akkor, hogy Brassai szerint az ige utáni bővítmények csak másodrendü hangsúlyúak lehetnek? Úgy gondolom, a magyarázat a másodrendü hangsúly definíciójában van.

Brassai nem határozta meg az említett hangsúlyfokok fonetikai tartalmát, de az nyilvánvaló, hogy elsőrendü hangsúlyon olyan szótag hangsúlyfokát értette, amely nemcsak hangerejével emelkedik ki a hangsúlytalanok közül, hanem azzal is, hogy dallamot indít. Hogy Brassai a másodrendü hangsúlyon mit értett, azt abból tudjuk meg, ahogy a Megérkezett a vendég mondat hangsúlyozását magyarázta. Brassai szerint, ha a Megérkezett a vendég mondatban a vendég szó „tudandó” (azaz „,nem-tudott”, vagyis „,új”) elem, akkor a másodrendü hangsúlyt kap (1889. 399). Ha most kijelöljük ezt a mondatot, arra vigyázva, hogy ne csak az igéje, hanem annak bővítménye is új információt hordozzon, tehát pl. válaszként a Mi történt? Kérdésre, akkor nagyjából a következő prozódiai megoldást kapjuk: 
(4) a Brassai-féle felfogásban:

1

Meg-

ven-

érkezett a

dég.

zöm

A példa elemzése alapján arra a következtetésre kell jutnunk, hogy Brassainál a másodrendü hangsúly olyan, mint az elsőrendü, csak gyengébb. A másodrendű hangsúlyú szótag is hangerővel és dallamindítással (elől eső dallam indításával) emelkedik ki a hangsúlytalan szótagok közül, de hangereje valamivel gyengébb és hangmagassága valamivel alacsonyabb, mint az elsőrendủ szótagé. Vagyis Brassainál az elsőrendü hangsúly és másodrendű hangsúly között pusztán mennyiségi különbség van, minőségi különbség nincs. Sajnos azonban ezt a tényt Brassai nem tette elég nyilvánvalóvá, sőt tulajdonképpen elfedte azáltal, hogy különböző névvel illette a két, minőségileg nem különböző hangsúlyt. Ezért számos korabeli és későbbi kritikusa úgy vélhette, hogy amit Brassai másodrendü hangsúlynak tart, az minőségileg is más, mint az elsőrendü hangsúly, vagyis hogy a másodrendü hangsúly puszta hangerö-többlet, dallami kitüntetettség nélkül, vagyis nem igazi akcentus. Ezt kell feltételeznünk, amikor olyan véleményeket olvasunk, mint pl. A már említett Joannovics-idézetek, hogy ti. Brassai „olyan hangsúlyozást teremt, a mely a magyar beszédet megfosztja accentusainak nagyobb részétöl" (Joannovics 1889. 103), illetve hogy „'nem-tudott eszme' és 'másodrendủ hangsúly'.: Ez a kettő nem illik együvé." (i.m. 110).

a (2a)-ban összefoglalt kifogás nem merülhet fel, ha elsőrendü hangsúlyúnak tekintünk valamennyi olyan szótagot, amely dallamindító és a hangsúlytalan szótagokhoz képest hangerőtöblettel rendelkezik (függetlenül a hangerőtöbblet konkrét mértékétől), másodrendü hangsúlyúnak az olyan szótagokat, amelyek csak hangerötöbbletükkel emelkednek ki a hangsúlytalanok közül, de nem indítanak dallamot, és hangsúlytalannak az olyan szótagokat, amelyek sem hangerötöbblettel, sem dallamindítással nem emelkednek ki. Ezt a javasolt új hangsúlyfelfogást (vö. Varga 1994. 492) mutatja az (5) táblázat:

\begin{tabular}{|l|c|c|}
\hline JAVASOLT HANGSÚLYRSZ. & Hangerőtöbblet & Dallamindító \\
\hline elsőrendű hangsúly: & + & + \\
\hline másodrendű hangsúly: & + & - \\
\hline hangsúlytalan: & - & - \\
\hline
\end{tabular}

A javasolt új rendszerben tehát az elsőrendű hangsúly a Brassai-féle elsőrendủ és másodrendủ hangsúlyoknak felel meg; a másodrendü hangsúly és hangsúlytalanság pedig a Brassai-féle hangsúlytalanságnak felel meg: 
(6)

\begin{tabular}{|l|l|}
\hline JAVASOLT HANGSÚLYRSZ. & BRASSAI-FÉLE HANGSÚLYRENDSZER \\
\hline \multirow{2}{*}{ elsőrendü hangsúly } & elsőrendü hangsúly \\
\cline { 2 - 2 } & másodrendü hangsúly \\
\hline másodrendü hangsúly & hangsúlytalan \\
\hline hangsúlytalan & \\
\hline
\end{tabular}

Igaz, hogy a mondatzömben az ige után álló elsőrendű hangsúlyú szótagok hangerőtöbblete és induló magassága elmaradhat a mondatzöm élén álló elsőrendủ hangsúlyétól, és ezért az ilyen szótagok hangsúlya valamivel gyengébb lehet az utóbbinál. Hogy ennek oka a lesodródás fiziológiai jelensége-e, vagy a Nuclear Stress Rule speciális magyar változata-e, ahogy É. Kiss Katalin (1987-88) feltételezi, vagy esetleg mindkettő, az jelen vizsgálódásunk szempontjából közömbös. A lényeg az, hogy elsőrendü hangsúlyúnak minősítjük mindazokat a szótagokat, amelyek a magyar hanglejtésrendszer valamelyik dallamát (az ún. karakterdallamok valamelyikét) indítják, és a hangerőtöbbletnek bármely értékelhető fokával rendelkeznek.

Az itt javasolt háromtagú hangsúlyrendszerrel a (4) mondat prozódiáját így lehet jellemezni:

(7) = (4) a javasolt felfogásban:

1

$$
\begin{gathered}
1 \\
\text { Meg- } \\
\text { ven- }
\end{gathered}
$$

érkezett a

dég.

zöm

Ebben a rendszerben a vendég szó akkor kap másodrendü hangsúlyt, ha pusztán hangerőtöbblettel emelkedik ki hangsúlytalan környezetéböl, de dallamot nem indít, vö. (8):

(8) a javasolt felfogásban:

1

Meg-

érkezett a vendég.

zöm

A (8)-ban a vendég szó ismert információt hordoz, mert a mondat válasz pl. erre a kérdésre: Mikor jön már a vendég? Eszerint a (7) változat az alapvető forma, melyből a (8) változat igen egyszerủen, a második hangsúly redukciójával állítható elö, ahogy a (9) mutatja:

$(9)$
1
1
1
2
Megérkezett a vendég. $\rightarrow \quad$ Megérkezett a vendég. 
A Brassai ellen irányuló korabeli kritikai észrevételek (2b) pontja szerint a mondatzöm belsejében (az ige után) sorakozó bővítmények hangsúlya alkalmasint még kiemelkedőbb is lehet, mint a mondatzöm élén álló elem hangsúlya. Ilyen a Simonyitól származó példa: Fordította pedig 'Szász Károly (Simonyi 1884. 128). Mint korábban javasoltam, az ilyen mondatok főhangsúlyos elemét antifókusznak hívhatjuk (Varga 1982). Ha Brassai megemlítette is a van 'pénze, van 'háza, van 'telke példát, ahol a felsorolt fóneveken marad csak a hangsúly, az ilyen eseteket érdemben nem tárgyalta. Ez azonban nem is volt dolga, ha csak az alapvető hangsúlyozási formát kereste. Az antifókuszos hangsúlyozás nem alapvető, hanem levezetett prozódiai séma. Mint ilyen azonban közvetlenül érvül szolgál a mondatzöm alaphangsúlyozásának Brassai-féle leírásával szemben. Ha ugyanis Brassait követve azt valljuk, hogy a kiinduló képletben elsőrendü hangsúly áll a zöm élén és másodrendü az ige utáni bövítményen, akkor a levezetéshez két lépés kell:

$$
\begin{aligned}
& \begin{array}{lllllll}
\text { (10) } & 1 & 2 & 1 & 1 & 2 & 1
\end{array} \\
& \text { Van pénze } \rightarrow \text { Van pénze } \rightarrow \text { Van pénze }
\end{aligned}
$$

Ha viszont az (5)-ben bemutatott hangsúlyrendszert követve azt fogadjuk el alapvető hangsúlyozási formának, amelyben két elsőrendü hangsúly van, a levezetés egyszerübbé válik:

$$
\begin{aligned}
& \text { (11) } \begin{array}{llll}
1 & 1 & 2 & 1
\end{array} \\
& \text { Van pénze } \rightarrow \text { Van pénze }
\end{aligned}
$$

5. Térjünk most át az inchoatívum prozódiájával kapcsolatos kritikai észrevételekre. A (3a) szerint az inchoatívum hangsúlytalanságának a tétele azért nem állja meg a helyét, mert ha az inchoatívumban pozitív jellemü kifejezés áll, akkor az elsőrendű hangsúlyt kap. Az ilyen esetekben É. Kiss Katalin szerint (1987-88) nyilvánvaló a Brassaival vitatkozók tévedése; hiszen ,azok a kifejezések, melyeket föhangsúlyos topicnak vélnek, főhangsúlyos kvantifikált kifejezések", és mint ilyenek, nem az inchoatívum, hanem a zöm részei. É. Kiss szerint „ezeket - legalábbis a jól-t, az egészen-t és hasonlókat - Brassai $\mathrm{F}$ pozícióban állóknak, a fókusz (azaz nála jelző) részének tekintette". Sajnos, ebben azért Brassai nem volt ilyen világosan értelmezhetö- Mivel lehetetlennek tartotta, hogy a zöm élén az ige előtt, tehát a jelző pozícióban egynél több bővítmény kapjon akcentust (hacsak nem mellérendelt bővítmények azok), Brassai tiltakozott a (12) alatt bemutatott hangsúlyozás ellen:

$$
1
$$

Az állam érdeke is azt kívánta, hogy...

Azt állította, hogy csak a (13a) vagy (13b) helyes (vö. Brassai 1889. 401 - 402):

(13) a.

Az állam érdeke is azt kívánta, hogy...

b.

Az állam érdeke is azt kívánta, hogy...

Brassai a (13a)-t tartotta valószínübbnek, és abban a pozitív kifejezést (az állam érdeke is) inchoatívumnak tartotta. Mások viszont úgy ítélték, hogy a (12) is helyes. Csakhogy ebben a mondatzöm hangsúlyos része (a jelző avagy az É. Kiss-féle fókusz pozíció) már ki van töltve. Ezt pedig Brassai szerint az inchoatívum előzi meg. Vagyis éppen Brassai alapján hihették a korabeli és későbbi nyelvészek, hogy a (12) pozitívan kvantifikált kifejezése szintén inchoatívum. Ezért mondhatta Simonyi Zsigmond: „ennyiben már most módosítást szenved Brassainak az inchoatívumról adott jellemzése; láttuk ugyanis, hogy van két eset, melyben a z inchoatívumnak van hangsúlya" (Simonyi 1880. 291). (Az egyik esetben is-sel 
kapcsolt fogalom, a másikban is nélküli a pozitív jellemü kifejezés, pl. nagyon, sok, mind). Tehát Brassai nem volt egyértelmü a tekintetben, hogy a pozitív jellemü kifejezések az inchoatívumba tartoznak-e, vagy a mondatzömbe. A kérdést É. Kiss (1981c) tisztázta egyértelmüen, amikor az ilyen kifejezések számára külön kvantor (vagy Q) pozíciót nyitott a mondatzöm, vagyis a comment élén.

Végül a (3b)-ben megfogalmazott kritika szerint az inchoatívum azért sem lehet kötelezően hangsúlytalan, mert a benne szereplő kifejezések akkor is elsőrendü hangsúlyt kaphatnak, ha nem pozitív jellemüek, de új információt hordoznak, mint pl. Kicska már idézett példájában: Az 'új országgyülésen 'kemény tusák lesznek (1895. 341).

$\mathrm{Az}$ a Brassai-féle álláspont, hogy az inchoatívumban nem lehetnek hangsúlyok (még másodrendủek sem), kétségtelenül tarthatatlan. Hogy Brassai miért vallhatta ezt, annak valószínüleg Kicska találta meg az okát, amikor azt mondta, hogy Brassai a mondatokat kérdésekre adott válaszoknak fogta fel. Az ilyen válaszokban az inchoatívum gyakran régi információt hordozó, ismert elem, és mint ilyen, tényleg hangsúlytalan lehet a Brassai-féle értelemben véve. Így például ha a mondatunk válasz a Mi várható az új országgyülésen? kérdésre, akkor a válaszban a Brassai-féle hangsúlytalan inchoatívum a természetes (14a). A javasolt új hangsúlyfelfogásban ez másodrendủ hangsúlyú inchoatívumnak felel meg (14b):

(14) a. A Brassai-féle felfogásban:

1

$k e-$

Az új országgyülésen

mény tusák lesznek.

inchoatívum

zöm

b. A javasolt felfogásban:

1

2.

$k e-$

Az új országgyülésen

mény tusák lesznek.

inchoatívum

zöm

Csakhogy még az ilyen esetekben is célszerü egy olyan hangsúlyozási alapformából kiindulni, amelyben az inchoatívum új információt és következésképpen elsőrendü hangsúlyt hordoz. Ez azután másodrendủvé fokozódik le, ha az inchoatívum ismert információt tartalmaz, ahogy a (15) mutatja: 
(15) 1

1

Az új országgyülésen kemény tusák lesznek.

2 1

Az új országgyülésen kemény tusák lesznek.

Tény, hogy az új inchoatívum elsőrendü hangsúlya gyakran valamivel gyengébb a mondatzöm élének elsőrendü hangsúlyánál. Ettől azonban az általunk javasolt új hangsúlyrendszerben elsőrendünek kell tekinteni, ha kimeríti az elsőrendü hangsúly ismérveit, azaz a hangsúlytalan szótagokhoz képest hangerötöbblettel rendelkezik, és dallamot indít. Az elsőrendü hangsúlyok eröbeli eltérések, fonológiai szempontból érdektelenek.

Hogy az inchoativum elsőrendü hangsúlya gyengébbnek tünhet a mondatzöm élének elsőrendủ hangsúlyánál, annak valószínüleg a következő egyszerü oka van. A mondatban sorakozó elsőrendű hangsúlyú szótagok mindegyike valamivel alacsonyabb szintröl indítja a maga eső dallamát, mint az előtte lévő. Ez a lesodródás jelensége. Ha annyi elsőrendü hangsúly van a mondatban, hogy a lesodródás által megkívánt hangterjedelem nem férne bele a beszélő hangterjedelmébe, akkor a beszélő automatikusan megtöri a lesodródást az olyan mondatösszetevők élén, amelyek több mint egy elsőrendü hangsúlyt tartalmaznak. Ha a mondatzömben egynél több elsőrendủ hangsúly sorakozik (és általában ez a helyzet), akkor a mondatzöm élén álló elsőrendủ hangsúlyú szótag nem sodródik le, és a lesodródás elmaradása nagyobb feltünőséget, nagyobb prominenciát kölcsönöz neki. A (16) meg- szótagja nem (vagy csak kisebb mértékben) sodródik le, és ezért a rajta lévő elsőrendü hangsúly feltünőbb, mint a (17) meg- szótagján lévő, ahol a lesodródás jelentősebb.

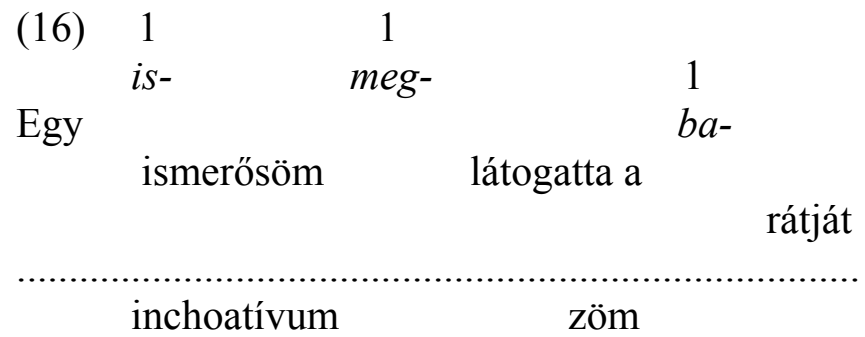

Az olyan mondatokban, amelyek teljes egészükben új információt közölnek, és mind az inchoatívumuk, mind a mondatzömük egy-egy elsőrendü hangsúlyt tartalmaz, nem tapasztaljuk az inchoatívum relatív gyengeségét. Ilyen a (17). Ez ugyanolyan dallammal és dinamikával fut, mint a (18), amelyben mindkét elem a mondatzöm része:

(17) $\begin{array}{cc}1 & 1 \\ \text { is- } & \text { meg- }\end{array}$

Egy

ismerősöm látogatott

$$
\text { inchoatívum zöm }
$$

$\begin{array}{ll}\text { (18) } & 1 \\ \text { fel- } & 1 \\ \text { Csak } & \text { fi- }\end{array}$

veszem a

zetésemet. 
6. Összefoglalásul a következőket szögezhetjük le: Brassai a magyar mondat egy fontos és jellegzetes hangsúlyozási képletét fedezte fel, amikor azt állította, hogy a mondatzöm élén álló elem elsőrendű hangsúlyú, az azt követő elemek másodrendű hangsúlyúak, az előtte levő inchoatívumban álló elemek pedig hangsúlytalanok. Ez a hangsúlyozás az olyan magyar mondatokat jellemzi, amelyeknek az inchoatívuma ismert információt hordoz. Brassai azonban ezt a képletet abszolutizálta, és az egyedül lehetséges vagy legalábbis alapvető formának tekintette. Ezzel egy túlságosan leszükítő álláspontot tett magáévá, amellyel kortársai vitatkoztak. Ehhez hozzájárult az is, hogy Brassai nem tisztázta kellő egyértelmüséggel a következő két pontot: (a) azt, hogy mi az elsőrendü és másodrendü hangsúly közötti fonetikai különbség, vagyis, hogy az általa elöírt másodrendü hangsúly csak erőben különbözik az elsőrendü hangsúlytól, de mindkettő dallamindító; és (b) azt, hogy az ige előtti ún. pozitív jellemü kifejezések nem az inchoatívumhoz, hanem a mondatzöm elejéhez tartoznak. Ezáltal további kritikáknak és félreértéseknek szolgáltatta ki magát.

A Brassai által leírt hangsúlyozási képletnek a mondatzömre vonatkozó részét valóban alapvetőnek tekinthetjük, ha az általa másodrendünek nevezett és félreértésre alkalmat adó hangsúlyfokot elsőrendünek nevezzük. Ekkor a mondatzöm hangsúlyozásának többi létező változata könnyen levezethető belőle.

A Brassai-féle hangsúlyképletnek az inchoatívumra vonatkozó része azonban alapvető formának sem tekinthető, mert a hangsúlytalan inchoatívumból (amely Brassai szerint egyedül lehetséges) nem vezethető le sem a másodrendü hangsúlyú inchoatívum, sem az elsőrendü hangsúlyú inchoatívum, pedig mindkettő létezik. Az elsőrendü hangsúlyú inchoatívumból, mint alapformából viszont minden más lehetőség levezethető.

\section{Irodalom}

Balassa József (1887-90), Hangsúly a magyar nyelvben. NyK. 21: 401-434.

Brassai Sámuel (1863-65), A magyar mondatról, II. III. Magyar Akadémiai Értesítő 3 : 3 128, 173-409.

Brassai Sámuel (1889), Szórend és accentus. Értekezések a Nyelv- és Széptudományi Osztályok köréből $14 \backslash 9$.

Brassai Sámuel (1888), Szerény észrevételek a „Hangsúly” címü értekezés irányában. Nyr. 18: 341-351, 396-406.

É. Kiss Katalin (1978), A magyar mondatok egyik szintaktikai modellje. NyK. 80: 261-286.

É. Kiss Katalin (1981a), Brassai Sámuel mondatelmélete. ÁNYT. 13: 91-102.

É. Kiss Katalin (1981b), Structural Relations in Hungarian, a „Free” Word Order Language. Linguistic Inquiry 12: 185-213.

É. Kiss Katalin (1981c), Topic and Focus: The Operators of the Hungarian Sentence. Folia Liguistica 15: 305-30.

É. Kiss Katalin (1987), Configurationality in Hungarian. Studies in Natural Language and Liguistic Theory. Dordrecht: Reidel.

É. Kiss Katalin (1987-88), Még egyszer a magyar mondat intonációjáról és hangsúlyozásáról. NyK. 89: 1-52.

Joannovics György (1889), Hangsúly. Nyr. 18: 61-68, 100-13, 153-60, 200-12, 249-62.

Joannovics György (1903), Szórendi tanulmányok. Nyr. 32: 16-19, 215-20, 318-24, 361-69, 486-90. 
Kicska Emil (1890), Hangsúly és szórend. Nyr. 19: 6-18, 153-58, 203-09, 390-95, 433-40.

Kicska Emil (1891), Hangsúly és szórend. Nyr. 20: 292-98, 337-45, 385-94, 433-45, 481-91.

Kicska Emil (1895), Alany és állítmány. Nyr. 24: 337-46, 385-91, 435-47, 537-54.

Simonyi Zsigmond (1880), Az ,is” szórendi szerepe, Nyr. 9: 289-99, 337-45.

Simonyi Zsigmond (1884), „Fordul elö”. Nyr. 13: 356-64.

Simonyi Zsigmond (1902), A magyar szórend. Nyr. 31: 57-61, 121-29, 180-86, 234-41, 289-301, 359-79, 424-41, 473-96.

Varga László (1982), Két szintaktikai pozícióról. MNy. 78: 159-69.

Varga László (1986), Vélemények a magyar mondat hangsúlyozásáról - avagy Brassai és a többiek. NyK. $88: 181-88$.

Varga László (1994), A hanglejtés. In: Kiefer Ferenc (szerk.) (1994), Strukturális Magyar Nyelvtan 2 : Fonológia. Budapest, Akadémiai Kiadó, 468-549. 